\title{
Outreach Strategies in the Wake of NATO and EU Enlarge- ment: Refocusing on the Partnership for Peace
}

\section{Jean-Jacques de Dardel ${ }^{*}$}

As a dedicated non-member country, you can trust Switzerland to be strongly committed to upholding the status of those states that will be left out of future rounds of NATO and EU enlargement. However, this natural tendency of the Swiss should not be taken as a sign of blind instinct or unsophisticated conservatism. We may not be candidates for membership in NATO for valid historical reasons, and we may be regrettably slow on our path towards full integration in the EU. But we do nevertheless have a perspective on the evolution of our continent, on global security, and on the principles and references that we think should guide meaningful progress towards enhanced stability and prosperity. It is in this sense, and because of a set of reasoned convictions, that we favor patterns of openness, outreach, and cooperation between the numerous bodies we belong to, as well as the few to which we remain outsiders.

Hence our interest in post-enlargement outreach strategies. Such strategies, we believe, are significant, both at the political and at the technical level. In choosing which aspects to concentrate on, we will limit the present study to the rationale for continued openness and outreach. Considering that none of the EU's recent mishaps or setbacks have had the effect of modifying its core objectives or its attractiveness to non-members, we will first look at the recent evolution experienced by NATO before making a case for geographic as well as thematic outreach strategies.

The Prague Summit, which took place less than a year ago, was widely seen as a success for NATO. The final phase of the second round of enlargement since the fall of the Berlin Wall was formally launched barely eight years after the newly invented Partnership for Peace first attracted former Soviet republics or satellites to NATO (along with some other partners). Russia - apparently satisfied with the enhanced NATO-Russia Council-barely objected to NATO's eastward expansion. Major decisions were made to transform the command structures of the Alliance. Europeans agreed to fill some of the gaps that separate them from the Americans at the technological level. The full launch of the NATO Response Force was, and still is, scheduled for 2006. NATO seemed to be back on track for playing a relevant role in the future.

But soon thereafter, the picture changed quite dramatically. Only a few months later, in the spring of 2003, most of the major international organizations appeared to be in bad shape. The UN, after failing to provide an international mandate for the Anglo-American decision to invade Iraq, was simply ignored. The marginalization of the UN continued after the war was formally over, and it required the tragic death of Sergio Vieira de Mello and twenty other UN staff to jump-start a new debate about giving the UN a more significant role in Iraq. The EU, for its part, was deeply divided on the

Ambassador Dr. Jean-Jacques de Dardel is Head of the Center for International Security Policy, Federal Department of Foreign Affairs, Bern, Switzerland. 
Iraq issue, and ultimately found itself paralyzed. More recently, the WTO suffered yet another setback, this time in Cancun, which could lead to a further shift away from multilateralism in the economic sphere. And NATO? NATO's only significant nonmove before the war was its inability to provide security assurances to Turkey, as disagreements between its member states proved to be too deep to resolve. Beside that episode, NATO did not play any role in the Iraq conflict — because it was never asked to play a role.

However, this situation should not have come as a total surprise. Indeed, even during the Kosovo crisis, it may well have been the case that NATO planned and carried out the war, but the strategic decisions were made on the other side of the Atlantic, and performed by U.S. means, sometimes even without the Alliance being fully informed.

It is true that on September 12, 2001, in a much-heralded decision, NATO invoked for the first time in its history Article V of the Washington Treaty. But, however politically meaningful that step may have been, the fact is that during the campaign in Afghanistan NATO was left to play a merely symbolic role, providing only five AWACS airplanes to the U.S. effort. It was involved neither in the planning nor in the execution of the operations in Afghanistan.

The same pattern was to repeat itself in the spring of 2003 in the context of the Iraq crisis.

Still, in view of this merely symbolic role played by (or granted to) NATO during all recent military campaigns, it is interesting to look at the role NATO played in the stabilization and reconstruction processes that followed those campaigns. In Bosnia and Kosovo, NATO has been the major actor - through IFOR/SFOR and KFOR - in providing security, under a UN Security Council mandate. Deceptively, on the other hand, in Afghanistan NATO was initially not given any role in 2001, even though some of its members participated on an individual basis in ISAF. And in Iraq, except for providing an indirect assistance to Poland, NATO was left without any direct role to play.

However, in Afghanistan, the strains put on those countries that assumed the command of ISAF, as well as the disadvantages of changing the command structure every few months, paved the way for NATO to eventually take over the command of the multinational force, whose mandate might even be extended beyond Kabul in the near future. Given the difficulties encountered by the occupying powers in Iraq, we should not rule out that a similar outcome could also take place in that country in the coming months.

Could this be a new pattern? The high intensity conflict phase is handled by the United States, possibly assisted by some of its closest allies, while the post-conflict phase, which requires time, patience, and perseverance, opens the way for NATO participation. 
In other words, the debate about the continued relevance of NATO, which focused, as U.S. Senator Lugar put it some ten years ago, ${ }^{1}$ on its ability to engage in "out of area" actions, lest it be put "out of business," seems to have led to a rather unexpected new role for NATO, which we could dub "out of step." Whereas the Alliance has always been intended as a tool for war, it now seems to have found a new mission, ${ }^{2}$ and a new raison d'être, as a tool for peace-keeping and post-conflict stabilization. Hence, it can be said that NATO did in fact find new business, out of area and out of step.

Such a pattern exemplifies how difficult life has become these days for an alliance in the traditional sense. Rather than by relying on a well-established and functioning alliance, with its formal mechanisms for common decision-making, today's conflicts are fought by ever varying ad-hoc groups of states, if not by one lone superpower-adhoc posses that have entered the vocabulary of international relations as "coalitions of the willing." This implies that varying numbers of countries commit assets at the peak of a crisis on a case-by-case basis, but - and this is an important characteristic that should not be downplayed-without having formal decision-making rights over the overall strategy.

In view of this evolution, it seems ironic that the expansion of NATO announced in Prague will probably become effective at a time when NATO will no longer be the Alliance it was meant and seen to be. That will mean for the Membership Action Plan countries that, although they may sense that their accession to NATO solves their main security concerns, as defined in traditional Soviet-centered terms, they may well find themselves continuously challenged by demands to join ad-hoc U.S.-led coalitions. In the process, they may find themselves more directly in the line of fire than they first bargained for, certainly more than if they had adopted a more restrained approach to security strategies. This, in turn, might affect those countries' stance towards the European Union Security and Defense Policy. Since public opinion in most countries might well develop a growing tendency to reject frequent partaking in punitive actions and otherwise lethal operations, we may see an increased interest in EU-led missions as a substitute for joining all ad-hoc coalitions led by the U.S.

Having said this, do alliances such as NATO belong to the past, and is the EAPC framework redundant or obsolete?

Well, as for NATO, it should be said that, although ad-hoc coalitions might be more flexible than a relatively bureaucratized and therefore more rigid formal alliance, it is hard to imagine states, even the most supportive ones, being ready and willing to be excluded for a prolonged period of time from a formal body dedicated to common decision-making on an equal basis. Moreover, with its history of over half a century,

${ }^{1}$ Senator Richard G. Lugar, "NATO: Out of Area or Out of Business. A Call for U.S. Leadership to Revive and Redefine the Alliance," Speech at the Overseas Writer's Club, Washington D.C., 24 June 1993.

${ }^{2}$ General agreement on the necessities of tackling the threats of terrorism and the proliferation of weapons of mass destruction on a worldwide basis has quickly and no doubt lastingly established NATO's new "out of area" vocation. 
NATO has developed such institutional power that it simply cannot disappear. ${ }^{3}$ On the contrary, NATO's path over the last decade has shown how a well-functioning organization whose core mission suddenly becomes irrelevant is able to constantly reinvent itself and adapt to a changing environment. With ten countries joining the Atlantic Alliance within a five-year span (and a few more still wanting to), NATO doesn't seem that unpopular or doomed after all.

And that enlargement cannot help but strengthen one defining element of the new essence of NATO: with twenty-six partners, it is bound to become an even more political organization, open to varied discussion. This evolution should reinforce, in turn, its purpose as a strategic forum for defining reconstruction and stabilization policies, as well as overall political frameworks, instead of limiting its scope to purely military joint operations. Indications are that even France, as it shifts away from its longstanding policy of balancing U.S. predominance by remaining aloof from actions that it saw as excessively U.S.-led, might want to use NATO in its new function as a political arena to the full, so as to promote its own set of values, such as the virtues of international law. ${ }^{4}$

As for the EAPC/PfP, it seems self-evident that the goals of interoperability and cooperative endeavors retain all of their validity, irrespective of the changed member to non-member ratio, both as a tool to enable wider ad-hoc coalitions and to prepare for common peace-keeping and post-conflict reconstruction actions. Viewed from the Swiss perspective, and to put it bluntly, since both enlargements were decided, and however excluded from that particular process we may be, we have been rather more than less solicited to take part in coalitions and international combined civil and military stabilization actions, which goes to show that, in practical terms, the advantages of the EAPC/PfP framework are increasingly invoked and required.

$* * * * *$

This brings us to a few thoughts on the need for new post-enlargement outreach strategies in the security field and on their appropriate form.

The European security landscape is currently undergoing a profound transformation, both in terms of geography and in terms of the nature of threats.

When NATO expands next year, it will extend all the way to within $300 \mathrm{~km}$ from that ancient capital of Russia, Saint Petersburg. It will also control large chunks of the

3 And it certainly doesn't intend to, since it is about to build a grand new building to extend its premise.

4 As was well described and announced by the Jean Monnet Professor of European politics at the University of Bath, and associate fellow of IFRI, Jolyon Howorth, in "La France, l'OTAN et la sécurité européenne: statu quo ingérable, renouveau introuvable," Politique étrangère (No. 4, 2002): 1001-16. 
Northern Black Sea coast. For its part, the EU will soon integrate ten new members. Among them, Malta is less than $400 \mathrm{~km}$ away from Tripoli, while Cyprus' closest neighbors are places like Beirut, Jerusalem, or Ramallah, very far away from Brussels.

This dual enlargement process marks the acknowledgement of a decade of a painful but ultimately successful transformation process of all prospective members towards political pluralism, respect for fundamental human rights, and a market economy. Integrating these countries into the two international bodies will significantly enhance their security, as well as that of the EU and NATO. However, the fruits of increased integration and stability can only be enjoyed by all of us if the new external borders of NATO and the EU are prevented from becoming new frontlines, dividing the Eurasian and Euro-Mediterranean areas into two parts: one where democracy, the rule of law, and increasing economic prosperity offer hope and prospects for everyone; and another where a number of authoritarian regimes are left to their own devices, economic downturns heighten frustrations, and corruption is left unchecked, thus leading to widespread misery and resignation.

Indeed, it is a sense of a greater and wider future, as well as a certain positivist vision, that has made those enlargements possible. Even though the need for a pause, a rest, and a digestive nap may be understandable after such accomplishments, the momentum behind them should not be lost. To be sure, if it was good policy to want to consolidate the new security landscape after the fall of the Berlin Wall, if it made sense to solidify new patterns of friendships and alliances in reference to failed dogmas and the Soviet menace, NATO and the EU have nothing to gain today and tomorrow from a fixation on past tensions and lines of division that would prevent it from turning to future potentialities.

In this respect, we should remember Alyson Bailes' comments at our European Security Studies Group meeting in Riga in September 2002. She referred to NATO's interest in addressing all 'inclusive' security activities, meaning the various 'soft' or 'indirect' security processes going on in various European regions (cross-border frontier management, joint peacekeeping forces, sub-regional organizations against new threats such as pollution and natural and man-made disasters, as well as transparency and confidence-building measures). As she stated, these security activities "can all help to ensure that NATO's new boundaries do not represent harmful dividing lines, or mark a sharp drop-off in terms of everyday security experience."

Along this line of thinking, we could add that the prospects of new dividing lines arising at the borders of NATO and the EU are very real, since these lines do not follow only government-defined institutional boundaries, but are also the result of differences in culture and public opinion. It should be stressed, for instance, that however outspokenly divergent the official policies of the U.S. and the EU may be, American and Western European public opinion remains very close on many issues, as demon-

5 Alyson J.K. Bailes, "NATO Enlargement and the Cause of Peace," Outline of the Intervention by the Director of SIPRI (Riga Summit, 6 July 2002). 
strated by Philip Gordon in an article published in Foreign Affairs. ${ }^{6}$ But among the remaining PfP countries, we must realize that, beyond the Western European Neutrals whose mindsets are totally compatible with NATO's and the EU's, many other more remote left-outs have deeper cultural and sociological differences that must be addressed patiently and comprehensively through substantive outreach strategies. This, by the way, also implies that attention must be duly paid to synergies and collaborations with other existing international bodies, such as the OSCE and the Council of Europe, that have long been in the business of bridging gaps and conveying humanistic values.

Thus, next year's two enlargement processes should not be an end. They rather should mark the beginning of a reinvigorated outreach strategy in order to assist those countries left on the outside looking in. While the substantial involvement of the international community in the Western Balkans must be maintained, two areas need our particular attention in the years to come:

A. The countries of the South Caucasus and of Central Asia are already part of the EAPC/PfP, as well as of the OSCE. But frozen and open conflicts in the Caucasus are a permanent threat to stability. Central Asia, for its part, has become a major stage in the global war against terrorism in the aftermath of September 11. Western interest in this area arose overnight. However, two years on, as most of the public attention is now directed towards Iraq, Central Asia is at risk of being forgotten once more. This would be a fatal error. The countries along the historic Silk Road need an outside engagement in order to curb growing authoritarianism and repression, to improve the still largely gloomy economic situation, and to fight against the drug flow from nearby Afghanistan. Above all, Central Asian states must be persuaded of the benefits of regional cooperation. The EAPC/PfP is an adequate instrument to tackle the new security threats and issues that are crucial to Central Asian countries. It is also a useful tool to bring them together in cooperative networks.

B. As the cases of Malta and Cyprus mentioned above make clear, the EU will have a foot on the doorstep of the Maghreb and the Middle East. We cannot

${ }^{6}$ Philip H. Gordon, "Bridging the Atlantic Divide," Foreign Affairs 82:1 (January/February 2003): 70-83. Gordon quotes the September 2002 opinion poll sponsored by the German Marshall Fund of the United States, deemed to be the most comprehensive poll of U.S. and European foreign policy attitudes ever taken, that showed "more similarities than differences in how American and European publics view the larger world." Interestingly, the poll disclosed that "Americans expressed discomfort with unilateralism, with 61 percent in favor of a multilateral approach to foreign policy problems and 65 percent saying that the United States should invade Iraq only with UN approval and the support of its allies. Even on the issue of the use of force, Europeans were at least in principle as ready as Americans to use force to uphold international law ( 80 percent to 76 percent), to help a population struck by famine ( 88 percent to 81 percent), to liberate hostages ( 78 percent to 77 percent), or to destroy a terrorist camp ( 75 percent to 92 percent)." 
remain indifferent to the situation prevailing within the countries of the Southern and Eastern Mediterranean. Political inertia could lead to further violence, economic stagnation, and extremism, and an explosive demographic situation might lead to massive migration flows. In other words, the security and stability of the southern members of the EU and NATO - and ultimately of the whole of Europe - will be increasingly linked to what happens on the other side of the Mediterranean. An extensive security dialogue on a wide range of military and non-military security issues is a necessity. Beyond a dialogue, common projects leading to increased mutual confidence should be envisaged as well. As Ronald D. Asmus states in the latest issue of Foreign Affairs, "[NATO] should look for ways to reach out to other Arab states in the region, drawing on the experience of the Partnership for Peace." 7

In short, the Western Balkans, but also the Caucasus and Central Asia, as well as increasingly the Mediterranean littoral, require engagement by the European and EuroAtlantic security organizations. Only a coherent geographical outreach strategy will render EU and NATO enlargement truly conducive to strengthened overall stability.

Let us add, in this context, that it is quite understandable and unavoidable that Europeans within NATO and the EU, be they old or new members, should focus primarily on the challenge of finishing the peaceful integration of their continent and widening its security structures. So while Washington may concentrate on global developments (and may hence have little time to devote to secondary areas and problems), the Europeans might well tend to become inward-looking for a while. As both organizations concentrate on tackling daily adjustments and the manifold technical necessities of expansion, they may let themselves be distracted from the bigger picture. This would indicate shortsightedness, which could spell new trouble to come. The reality of the bigger picture and the necessities of the long-term purpose will not subside, and will continue to require deft attention. In this sense, keeping the present forum for partnership active is an investment in future solutions to predictable problems, and in the eventual resumed openness of the EU and NATO.

From another perspective, we should stress that the European security landscape is not only undergoing a transformation in geography, but also one in terms of the evolving nature of security threats.

Long gone are the days of the Cold War, when the large armies of the two blocs faced and threatened each other. The Partnership has reacted to the new security threats by addressing early on issues such as the dissemination of international humanitarian law or the fight against the spread of small arms and light weapons. The (fortunately failed) attack on an airplane taking off from Mombasa in 2002 showed the increasing threat emanating especially from light weapons, such as portable missiles or

7 Ronald D. Asmus, "Rebuilding the Atlantic Alliance," Foreign Affairs (September/October 2003). Asmus is a Senior Transatlantic Fellow at the German Marshall Fund of the United States. He served as Deputy Assistant Secretary of State for European Affairs from 1997 to 2000 . 
MANPADs. In addition to the fight against the proliferation of small arms, the specific issue of light weapons should be given increased attention. Concerning international humanitarian law (IHL), there still are important gaps in the availability and translation of basic legal texts, and there is much room for improvement in the role given to IHL training and observance in the overall pattern of training of many security forces, especially in relation to their increasing deployment on missions of post-conflict stabilization, peacekeeping, and reconciliation.

The adoption of the Action Plan against terrorism has provided the Partnership with a tool to address terrorism from various angles, such as its economic dimension, particularly in the fight against the financing of terrorism or threats to cyber security. These are two areas where Switzerland develops various activities, and it organized two focused PfP workshops in September and in November 2003. Moreover, many security bodies remain unprepared or ill equipped to address issues such as transnational movements of terrorists, organized crime, drugs, arms and, human beings, which makes the reform of the security sector an important task. Such reform must go beyond defense sector reform to include all so-called 'power ministries,' such as police forces, border guards, or intelligence services. Besides helping to address the threats enumerated above, security sector reform is an important step in the democratic transformation process. Security sector reform should be given an adequate foundation within EAPC/PfP, ideally through an action plan or at least a working chapter. Indeed, a strengthened focus on such wider themes in the context of the PfP might well help all of the NATO and EAPC countries to continue to engage in lively outreach actions.

Take it from the ever quality-conscious Swiss: thanks to its operational and flexible character, EAPC/PfP is an instrument fully adequate to develop outreach strategies by addressing the many non-military threats that the Euro-Atlantic area faces today. It should, and in fact could, be better used not only within a purely NATO/non-NATO context, but could well also serve as a model for increased EU/non-EU cooperative strategies. 


\section{Bibliography}

Howorth, Jolyon. "La France, l'OTAN et la sécurité européenne: statu quo ingérable, renouveau introuvable." Politique étrangère (2002). 